\title{
An Analysis of Flouting Maxim in a Talk Show Program in Indonesia
}

\author{
Ismi Narulita Firda, Didin Nuruddin Hidayat, Alek, Nurhalimah \\ UIN Syarif Hidayatullah Jakarta \\ Email: didin.nuruddin@uinjkt.ac.id
}

\begin{abstract}
This paper is a flouting maxim analysis in Sapa Indonesia Malam talk show on Kompas TV in which Jerinx or I Gede Ari Astina became a guest star in this talk show. The present study aims to analyze a conversation and dig out information about flouting maxims. In this present research, a conceptual framework of Grice's cooperative principle of flouting maxim was employed to analyze the data (Geis et al., 1976). The flouting maxim has four maxims: quality, quantity, relation, and manner. The method of this study was qualitative by using the utterances in the video conversation from the talk show in Sapa Indonesia Malam as analysis material, and the data were extracted from the video. This study's instrument was the transcript text of the utterances between the hosts and Jerinx as a guest star consisting of flouting maxims. The data were analyzed by using flouting of the maxim in Discourse Analysis' concept. This paper attempts to find the flouting maxims that mostly appear in the video conversation and determine the cause or reason for the maxim to emerge. The researchers comprehended the types of flouting maxims in the talk show, and then the researchers determined the types selected into categories based on guests' utterances. After that, the researchers analyzed the predetermined types. The study found some floutings of the maxims of relation. There were 50\% maxims of relation flouted by speakers, and from nine flouting maxims, the four data had the most reasons for appearing in the conversation.
\end{abstract}

Keywords: Cooperative principle, Flouting Maxims, Implicatures, Sapa Indonesia Malam

\section{INTRODUCTION}

Language has a pivotal position in this world. Since ancient times, humans have developed language according to communication needs (Amer \& Rogayah, 2017). Language for humankind is a way to sustain their lives, and humans are involved in all forms of conversation aiming to communicate their messages. A language can perform for oral and written communication (Ekah \& Akpan, 2018). The main thing about language is as a conveyance to inform and share thoughts and ideas through communication (Nastiti, 2018). Since language has a relationship with communication, it requires a speaker and interlocutor in every part of speech (Taylor-Rubin et al., 2017)also known as semantic dementia. To achieve communication goals, a speaker and interlocutor must cooperate to understand each other (Dimmick, 2017). It can interpret that speakers and listeners need to cooperate to deliver and get clear messages at each turn of utterances so that the 
cooperation that exists is that the speaker intends to convey the message clearly in the right way. Hence, the listener should understand the speaker's message in each speech.

Communication does not only use in daily life interactions, but also communication can be made on TV programs. The TV program has many types of presenting communication, both formally and informally. One of the TV programs that are currently famous among the community is a talk show. Talk shows are unique TV shows that many people recognize. The talk show is where the host and guest meet and discuss many topics raised by the talk show host, and it makes a difference between talk shows and other programs. Talk shows in Indonesia itself have many kinds of content. They are to provide information, entertainment, news, so forth. Talk shows are broadcasting Indonesia rapidly, some broadcast once a week, and some broadcast even every day. Some talk shows that are very famous for getting the latest information are those delivered by Aiman, Najwa Shihab, etc. One of the talk shows that the researcher will examine an event hosted by Aiman entitled Sapa Indonesia Malam. Sapa Indonesia Malam is a talk show on Kompas TV. During the pandemic, this talk show only interviews guest stars via video conference. Besides direct communication by speakers and interlocutors in a conversation requires good cooperation for communication goals, talk shows also require good cooperation to build smooth communication between host and guest. Then, to get good communication, Grice prompts his principle as known as the cooperative principle. According to Grice, in Geis et al. (1976), conversations would be smooth and goal accomplished if they followed the principles of cooperation related to the four maxims of conversation.

Levinson (1983) illustrates those four maxims. Firstly, maxim of quantity requires the contribution in communication as informative as is required yet no more informative than it should be. Secondly, the maxim of quantity needs a truth statement or communication. In this maxim, the speaker cannot lie and say the wrong things. Thirdly, Maxim of Relation requires relevant contributions. The latter is Maxim of Manner, this maxim directs the speaker to not ambiguity and obscurity expression in communication. It also requires a brief and orderly contribution.

Cooperative principles are intended to achieve communication goals. However, making good and successful communication is not an easy matter and sometimes it is tiring. There are still misunderstandings during communication from several factors. According to Sembiring and Ghozali (2017), flouting is a reality when a speaker cannot apply one or several maxims in their conversation and it confuses their conversation. Flouting maxim is a way to examine failures at maxim use. The flouting maxim covers the real meaning of a speech and makes hearers find the implied meaning (Lestari, 2019)people always communicate each other. Sometime people do not realize what they are talking about. To make a good communication, human must follow cooperative principles. That is why Grice offers to use theory of cooperative principle to avoid misunderstanding and misinterpretation between the speaker and the listener. However, some people do not fulfill those maxims to be used in the 
conversation for certain reasons, and when they violate the maxims it is called flouting maxims. A descriptive qualitative approach is used for this study because the data are in the form of words rather than of numbers and statistics. This study reveals that based on theory of Grice's Cooperative, there are four maxims which are flouted by the main characters of "Home Alone Part 2 'Lost in New York" movie this movie since 1992 directed and written by John Hughes. The result shows that there are four Maxims Flouted by the main characters there are flouting maxim of quality, flouting maxim of quantity, flouting maxim of relevance, and flouting maxim of manner. And there are several reasons of flouting those maxims are data finding also revealed that the communication could still even though the main characters flouting the maxims. Four reasons by the main characters to flout the maxims are competitive, collaborative, convivial, and conflictive reason. In terms of types, quantity maxim flouting is in the highest rank and relevance maxim flouting is in the lowest rank. In terms of strategies, overstatement is the most frequently used and metaphor is the most rarely used. Finally, dealing with reasons for maxim flouting, conflictive reason has the highest rank in its occurrence.Communication is a human activity everyday, people always communicate each other. Sometime people do not realize what they are talking about. To make a good communication, human must follow cooperative principles. That is why Grice offers to use theory of cooperative principle to avoid misunderstanding and misinterpretation between the speaker and the listener. However, some people do not fulfill those maxims to be used in the conversation for certain reasons, and when they violate the maxims it is called flouting maxims. A descriptive qualitative approach is used for this study because the data are in the form of words rather than of numbers and statistics. This study reveals that based on theory of Grice's Cooperative, there are four maxims which are floute..."," author":[\{“dropping-particle":",",fa mily":"Lestari", "given":"Nursuci Gunawan","nondropping-particle":",", parse-names":false,"suffix": "’'\}]," container-title":"Jurnal JOEPALLT (Journal of English Pedagogy, Linguistics, Literature, and Teaching. This can be found in interviews, talk shows, etc. Sapa Indonesia Malam is an example of an informal conversation, this is a program that the researcher can find a maxim which is aimed at the flouting maxim.

Directing the explanations above, this study is interested in investigating flouting maxim based on the video of Sapa Indonesia Malam talk show with Jerinx as an informant. I Gede Ari Astina or known as Jerinx is a musician and artist known for his band Superman is Dead (SID). He is a non-native speaker whose English is a foreign language for him. In this video, the host and guest star use Indonesian. Jerinx as a guest star was invited because the viral statement about COVID19 was a conspiracy. This video discusses Jerinx's statement regarding COVID19. During the talk show, Jerinx answered questions from the host with long answers, irrelevant explanations, explanations that were not at the point, answers that had no proof, and a lot of vague expressions. In this video, there is one host and 2 guest stars, however, the researcher only focuses on Jerinx's utterances. In this talk show, there are many problems that the conversation does not run smoothly, one of the problems is the flouting maxim. Since there were 
many conversational problems, researchers have formulated several questions to look at and answer about the flouting maxim. These research questions are: (1) what kinds of maxims are flouted by Jerinx in Sapa Indonesia Malam? (2) What is the most dominant flouting maxim type in this conversation? (3) What are the reasons for flouting maxims shown by Jerinx in Sapa Indonesia Malam? Besides, this research has various kinds of significance. Firstly, this can be additional information and insight into the English Literature Department. Secondly, this can find out how to communicate well by applying Grice's principle. Thirdly, it can find out some of the flouting maxims that often occur in communication. Lastly, this research can be used as an example of utterances analysis that is inconsistent with the purpose of communication carried out by the guest star.

In addition, this study has implication with language teaching and learning because the interaction is inevitable for language teaching and learning. Interaction between people in class or school is an essential point of language teaching because the purpose and how learning occurs is in the interaction, particularly related to the medium and learning object (Hall \& Walsh, 2002). Every interaction does not always follow the Grice rules, and the number of submission of excessive or irrelevant responses causes the flouting maxim in the classroom. Previous studies have examined the classroom's flouting maxim (Wahyudi et al., 2020; Safitri, Mega L; Seken \& Putra, 2012). This study intends to help readers find out how flouting maxim happens in a conversation and as student knowledge for good speaking. They can learn the basics of Grice's
Maxim, why someone can be said to be a flouting maxim and the reasons behind a flouting maxim. Researchers hope that further research will be carried out by readers in this field. Moreover, this research has the benefit of flouting maxims knowledge in the TV Talk Show: 'Sapa Indonesia Malam'. This study emphasizes the knowledge of the flouting maxim of relations flouted by the speakers and various reasons from one type of maxim. It expects as a reference for readers to learn how to analyze a conversation. This study's results are also aimed at readers and students who are interested in discourse analysis and want to research the flouting maxim with a different type of maxim.

\section{LITERATURE REVIEW}

Communication or conversation is carried out from humans who are already able to speak or even from the time of the mother's womb, this is done with awareness and effort to reach the target of a mutual communication agreement. Since communication is primarily to maintain human life, the communication must be carried out by both speakers and hearers. However, building good conversation is pretty hard, and there tends to be a lot of problems in communication. Because in conversation, it requires understanding both explicit and implicit meanings, but the most difficult is the implicit meaning. Meanings that are not conveyed explicitly are known as implicatures (Schneider, 2012). Besides that, there are so many things that make a hard conversation.

Importantly, subjects in conversation should obey several maxims to build successful conversation and to avoid misunderstanding. Rowe and Levine 
(2018) mention that CP is fundamental to the conversation maxim, and presume that everyone tries and works together to communicate and understand the meaning of a conversation. Lingual interaction has the rule of linguistics as known as Maxim. The maxim is the rules arranging the speaker's action, the utilization of language, and the speaker's interpretation of the speaker's actions and speech. Finch (2000) assumes maxims as an implicit principle on good communication. In addition, they can be stopped while such communication is not needed or intended.

Moreover, Yule, in Schneider (2012) defines maxim concisely. He illustrates four maxims, in quantity maxim needs to create contributions as informative as possible according to what is needed and not making it too informative than necessary. Quality maxim requires words that have proof and it does not use lack evidence, and do not say what you believe to be wrong. Then, the maxim of relations emphasizes that it must make a relevant contribution. Lastly, relation maxims need to prevent ambiguity and prevent obscurity of expression. However, subjects of conversation occasionally still did not comply with the rule and they flouted the maxim. Grice, in Cutting (2016), flouting maxim is an event that occurs when speakers either deliberately or not, they want the interlocutor to know or search for the intended meaning of the speaker. The situation becomes one of the factors that fail the listener to know an idea or the conclusion of a conversation (Gumperz, 1982).

The flouting maxim is a non-observance maxim that appears in conversation which means in discourse a resource book for students and a pragmatic. This happens when the speaker in the conversation does not follow the maxim yet wants the interlocutor to know the implied meaning (Thomas, 2013). Besides ignoring maxims, flouting the maxim is also neglecting the rule of cooperative principle whether consciously or unconsciously to flout a discourse when interacting. Flouting in the conversation can occur when the speaker frankly fails to inspect a maxim at what level it is uttered. Maxim flouting is one of disobedience that can only make a speaker create a deliberate choice without depending on the obeyed principles. Thus, the cooperative principle can be broken by conversation participants.

From the topic above, the present study aims to analyze a conversation of Jerinx in Sapa Indonesia Malam. This topic and explanation are similar to Marlisa and Hidayat's (2020) study, entitled The Analysis of Flouting Maxim In Good Morning America (GMA) Talkshow. Secondly, it is similar to Ayasreh et al. (2019). The first research has the gap with this study, it is the subject of this study speaks in Indonesian meanwhile Jackie Chan uses English, the quantity and manner are the highest maxims occurring in their research, and their subject of this research shows humor. Meanwhile, relation and quantity are the highest maxims occurring in this research, and Jerinx does not display humor, but rather creates a lack of manner in the interview. The latter research shows that the four types of maxims are flouted by the Arab leader during the interview by giving answers which he thought would convince their people. However, he was not cooperating with the interviewer. The second previous study is almost 
Ismi Narulita Firda, Didin Nuruddin Hidayat, Alek, Nurhalimah An Analysis of Flouting Maxim in a Talk Show Program in Indonesia DOI: https://doi.org/10.31605/eduvelop.v4i2.887

the same as the current research where the guest star made an irrelevant contribution.

\section{METHOD}

The method of this study is descriptive qualitative and data were extracted from a video. The instrument in this study was the transcript text of the utterances between the hosts and Jerinx as a guest star consisting of flouting maxims. The data were analyzed by using flouting of the maxim in discourse analysis' concept. Furthermore, after writing all the contents of the transcript in the downloaded video then the researchers did the translation from Bahasa Indonesia into English, and classified them according to the maxim flouted, identified the most dominant type of maxim being flouted, and explained behind that utterance is based on what Jerinx said. The third step of the data analysis was the data were described to answer those categories based on the research questions. In addition, this study analyzed the most dominant reasons among the utterances and looked at the various reasons that occured in flouting maxims of relation. This research is intended to see the kinds of maxims that are flouted by Jerinx in Sapa Indonesia Malam, to know the most dominant flouting maxim type in this conversation, and to explore the reasons for flouting maxims demonstrated by Jerinx in Sapa Indonesia Malam.

\section{RESULTS}

Eighteen utterances were obtained from the video conversation with Jerinx at Sapa Indonesia
Malam. The researchers classified the utterances according to the cooperative principle (Geis et al., 1976), as follows:

Table 1. Kinds of Flouting Maxim

\begin{tabular}{|l|r|r|}
\hline \multicolumn{1}{|c|}{ Types Flouting Maxim } & Percentage & Quantity \\
\hline Flouting Maxim of Quantity & $22 \%$ & 4 \\
\hline Flouting Maxim of Quality & $11 \%$ & 2 \\
\hline Flouting Maxim of Relation & $50 \%$ & 9 \\
\hline Flouting Maxim of Manner & $17 \%$ & 3 \\
\hline
\end{tabular}

The table indicates that eighteen data of maxim were found between the host and Jerinx in the talk show. This study discovered 9 utterances about the flouting of relation maxim (50\%), 4 utterances from the flouting of quantity maxim (22\%), 2 flouting maxims of quality (11\%), and 3 utterances of flouting the maxim in manner (17\%).

\section{The Flouting Maxim Types Happens In Sapa Indonesia Malam Talk Show}

The results of the host and Jerinx utterances were analyzed to determine the results of the Jerinx utterances. This data analysis will focus more on the flouting maxims of relation.

\section{The Flouting Maxim of Relation}

Datum 1

Host : Saya langsung menuju ke anda Bung Jerinx. Bung, anda punya tudingan bahwa COVID19/Korona yang luar biasa saat ini berbulan-bulan kemudian ada dari Januari di dunia dan kemudian mampir 
Ismi Narulita Firda, Didin Nuruddin Hidayat, Alek, Nurhalimah

An Analysis of Flouting Maxim in a Talk Show Program in Indonesia

DOI: https://doi.org/10.31605/eduvelop.v4i2.887

ke Indonesia dan membuat hari ini kita melakukan atau menjalani kehidupan yang sering dikatakan sebagai a new normal, sebuah kenormalan yang baru, dan anda menuding bahwa itu adalah sebuah konspirasi. Anda punya data?

I went straight to you, Brother Jerinx. Dude, you have an accusation that the extraordinary COVID19 / Coronavirus is currently there from January in the world and then stops in Indonesia and makes today we do or live a life that is often said to be a new normal, a new normal, and you point out that it is a conspiracy. Do you have data?

Jerinx : Iya, jika anda, Ok. Gini. saya balik lagi ke pola pikir ini ya. Masyarakat Indonesia percaya sama agama ga mayoritas? Masyarakat indonesia percaya sama Tuhan ga mayoritas? Oke, saya berani bilang a... agama itu salah satu teori konspirasi juga karena tidak ada. Bukti-bukti. Sains.

Yes, if you, ok. Like this. I come back to this mindset. Indonesian people believe in religion or not, the majority? Indonesian people believe in God or not, the majority? $O k, I$ dare to say $a . .$. religion is the one of conspiracy theory too because it doesn't exist. Proofs. Science.

\section{Datum 2}

Host : Kita bicara COVID dulu sebentar. Let's talk COVID first for a bit.

Jerinx : Ya, tapi disini kan kita bawa mindset kita agar lebih luas lagi. Jadi agar orang, agar orang-orang tidak langsung menyerang teori konspirasi itu adalah sebuah halu.
Hal yang halu.

Yes, but here we lead our mindset to make it even wider. So that people, so that people do not immediately attack the conspiracy theory as a hallucination. Hallucinations thing.

Datum 3

Host : Ini maksud anda sebuah buku ya? Ada buku itu ya?

You mean a book, right? There is a book, buh?

Jerinx : Ada dokumen nya rilis di at. www at.

There is a document released at. www. at.

\section{Datum 4}

Host : Itu swab test atau rapid test? Karena ada dua test. yang sering ada false negative dan false positive adalah rapid test bukan swab test.

Is it a swab test or a rapid test? Because there are two tests. that often have false negatives and false positives, it is a rapid test, not a swab test.

Jerinx : Swab test dan rapid test tuh hasilnya, keduanya tidak, tidak valid. Itu banyak menimbulkan ketidak apa kesimpangsiuran informasi tapi media selalu dengan gampangnya membawa narasi, jika semua orang yang. Jika swab test itu hasilnya itu sudah $100 \%$ sementara ilmuwan2 di negara maju yang jauh lebih pintar dari ilmuwan di indonesia. Mereka aja belum 1 suara. Tapi kenapa indonesia sangat takut pada WHO. emangnya who itu siapa sih? Bill gates itu siapa? Kenapa kita harus tunduk sama mereka itu saya ga ngerti. 
Ismi Narulita Firda, Didin Nuruddin Hidayat, Alek, Nurhalimah An Analysis of Flouting Maxim in a Talk Show Program in Indonesia DOI: https://doi.org/10.31605/eduvelop.v4i2.887

The results of the swab test and rapid test are both invalid. It causes a lot of confusion in information, but the media always easily brings up the narrative, if everyone. If the swab test is 100\%, scientists in developed countries are much smarter than scientists in Indonesia. They have not had to agree. But why is Indonesia so afraid of WHO. Who is WHO? Who is Bill Gates? Why do we have to comply with them? I do not understand.

\section{DISCUSSIONS}

\section{Maxim Flouting Reasons During Sapa Indonesia Malam Talk Show}

In this part, the researchers try to explore and analyze the reasons behind the conversation between Host and Jerinx in Sapa Indonesia Malam.

\section{The Flouting Maxim of Relation}

\section{Datum 1}

Jerinx has flouted many maxims of relation, one of them is utterances above. Here, he said something irrelevant to the question submitted by the host. Jerinx answered a question that was not related to COVID19 which he suspected was a conspiracy but instead asked back whether the Indonesian people believed in religion, he flouted maxims with reasons to develop the public mindset about conspiracy again. He also wanted to convey that the position of religion and conspiracy is the same, that is, both have no proof. Although the same, only the conspiracy that has been attacked. Moreover, after the conversation, the host still asks the same thing because it has not reached the desired information.

\section{Datum 2}

In datum 2, the flouting of maxim relation still showed that Jerinx still insisted on broadening people's mindset about conspiracy even though he did not answer questions from the host. Jerinx's reason is to make people not attack the conspiracy because of his accusations about COVID. After that, the host continued with other questions that were still about COVID.

\section{Datum 3}

Here, the datum indicated that Jerinx another flouting of the maxims. He still has not contributed any relevant contributions to the question. When the host asked about a book, he answered with a document on a website. It can be seen that his reason wants to convey the place where the documents that he usually reads about his accusations.

\section{Datum 4}

Based on datum 4, the relation of the maxim was flouted because he should answer only one of the two test kits as the host has clearly explained that only one is invalid. However, he stated that both tools were invalid which did not answer the host's question. In this datum, the reason behind his statement is to reopen that the media is involved in making the narrative that is not true and there is also a connection with WHO and Bill Gates.

Based on the finding above, it can be highlighted that the interviews in this talk show resulted in several flouting maxims, such as quantity, quality, manner, and relation. We noticed that most guests issued are flouting maxims of relation. Eighteen flouting maxims data had been spoken by guests, 
nine of them were flouting maxims of relation. This finding corresponded with several previous studies (Virgin \& Utami, 2017; Lisan, 2017; Rahmi et al., 2018) that these previous studies have a greater number of findings on the flouting maxim of relation. According to this study, many floutings in relevant maxim have different reasons. Several previous studies have discussed that many flouting maxims happen in speech acts because they want to show humor (Marlisa \& Hidayat, 2020; Aziz et al., 2019; Virgin \& Utami, 2017; Zebua, 2017). This is the biggest reason for the emergence of the flouting maxim in relation and manner in the talk show. From those previous studies, we could describe that many reasons for flouting the maxim of relations are due to humor. However, several previous studies were not due to humor, as in this study there were several reasons for the emergence of the flouting in the relations maxim.

The first datum revealed that Jerinx did the flouting maxim of relation because he changed the topic of conversation all of a sudden. It is similar to plenty of previous studies (Zebua, 2017; Al-Qaderi \& Alduais, 2019; Ayasreh et al., 2019), those studies showed that some interlocutors still answer though they changed the topic. Sometimes, it happens due to the question from the speaker. According to Ayasreh et al. (2019), their data showed that their research subject flouted the maxim of relations due to critical or conflictive questions. In their study, the subject wanted to mislead those who listened to the answer by making an inappropriate answer because the question created conflict. Moreover, the present study displayed that Jerinx replaced the topic because he lacked actual data, so he just gave another topic that religion is part of the conspiracy and this is an irrelevant answer to the question asked by the host.

Besides changing the topic abruptly, there are several reasons why speakers flout the maxim. Dwiwulandari and Dewanti (2020) is quite similar to the results of the second data, their study showed that there were subjects who flout the maxim relevance that changed the topic of conversation suddenly and there were also those who wanted to avoid answering questions. In this second discussion, Jerinx tries to avoid answering the host's question because he is still lacking in strengthening his statement and he is still unable to answer the topic that the host is questioning so he tries to avoid answering the host's question. According to Rahmi et al. (2018), the reason speakers avoid the question or topic being discussed is because they are faced with an unpleasant situation or topic. They also answer irrelevantly because they do not want to answer unpleasant topics and hope the listener understands them (Aisya \& Fitrawati, 2019)speakers are expected to obey the maxim of cooperative principles to convey messages effectively. However, many speakers disobey it for some reasons. Flouting of maxim is one of cases when speakers fail to observe the maxim to generate an implicature. This research aimed to find the types of flouting of maxim and the reasons of indirectness in flouting the maxim done by Politician guests in two episode of Mata Najwa Talk Show entitled Adu Lantang Jelang Penentuan and Babak Akhir Pilpres. The method of this research is descriptive research. The data of this research were the utterances of guests that flout the maxim of cooperative principles. It is found that there were total of 55 utterances that flout the maxim 
of cooperative principles that were analyzed. The results show that the Politician guests flout maxim of quantity and manner the most with frequency of $53.96 \%$ and $36.50 \%$. Flouting of maxim of quality and relation rarely appeared with the same frequency, $4.76 \%$. It is also found that the reasons of indirectness in flouting the maxim were vary such as interestingness, increasing the force's of messages, competing goals, and politeness. However, increasing the force of the messages and politeness are two reasons that occurred more frequent in comparison to interestingness and competing goals. This research implicated that politician guests convey messages by flouting maxim for many reasons in order to gain support from masses.","author":[\{ “dropping-par ticle":",",family":"Aisya","given":"Norin","nondropping-particle":",", parse-names":false,"suffix" :"”\},\{“dropping-particle":",,"family":"Fitrawati"," given":",,"non-dropping-particle":"”, ,parse-nam es":false,"suffix":"”\}],"container-title":"E-journal of English language \& Literature","id":"ITEM1 ”, " i s s u e " : 4 ", ” i s s u e d": $\{$ “d a t e parts":[[“2019”]]\},"page”:"42-55","title”:"An analysis of flouting of maxim performed by politician guests in Mata Najwa Talk Show in the episode of Adu Lantang Jelang Penentuan and Babak Akhir Pilpres","type":"article-journal","v olume":"8"],"uris":["http://www.mendeley.com/ documents/?uuid=d971cf39-b452-47cc-a6d7d3b59d6ba9e3","http://www.mendeley.com/ documents/?uuid=47aa8580-b68f-4c24-b357-f5f9 57aee723"]\}]," mendeley":\{“formattedCitation":"(Ai sya \& Fitrawati, 2019. This is the same as the speaker wanting to divert the question from the asker so that the purpose of the speaker's illocution is different from the social goal asked by the questioner (Aziz et al., 2019).

Another reason that makes speakers flouting the maxim of relations is the inability of speakers to maintain the topic (Thomas, 2013). Lisan's (Landscape, 2017) research on the same thing that the failure of speakers to hold the topic is one of the reasons for the flouting maxim of relations. The third datum shows that the speaker is confused or wrongly saying the answer according to the topic with the host, but he says something new and has nothing to do with the topic being discussed, which makes the speaker unable to maintain the topic of conversation. Furthermore, the last datum showed irrelevant answers because the speakers answered with the intention of mocking others. This reason has been supported by several previous studies (Marlisa \& Hidayat, 2020; Al-Qaderi \& Alduais, 2019; Ibrahim et al., 2018; Khosravizadeh \& Sadehvandi, 2011 in a movie entitled "Dinner for Schmucks". In addition, it seeks to find if there is any occasion in which one party opts out of the conversation. Dinner for Schmucks is an American movie which is the second version of A French film Le Diner de Cons; (dinner game; Sembiring, E \& Ghozali, 2017), they claim that the occurrence of speaker flouts the maxim is not only because they want to tease but also to mock of other people.

From the nine maxims of relation that have speaker flouts, these four data represent some of the reasons that appear most frequently in the flouting maxim of relations. Every conversation inevitably results in several flouting maxims of various maxim types. The subject can be a speaker or hearer. From 
every maxim that is said by the subject, they have different reasons. Thus, this study has examined that one maxim type alone can produce many different reasons. The reasons are different due to the various situations that occur in the conversation.

\section{CONCLUSION}

There are 18 data of flouting maxim found by the speakers, and the highest result is the maxim of relations. The researchers took the center of the discussion on the flouting maxim of relations because the results reached $50 \%$ and this maxim was mostly flouted by speakers who appeared on the Sapa Indonesia Malam talk show. This maxim appears the most because the speaker or Jerinx did not answer with relevant answers according to the topic.

The four reasons are changing the topic suddenly, avoiding answering questions or topics, failing to maintain the topic of conversation, and mocking other people or teasing. The whole reason occurs mostly in changing the topic suddenly due to Jerinx not considering the words according to the facts and data. This made him switch the topic with a new statement. The second most common in all previous studies were avoiding answering questions because of various conditions that could be unpleasant or sensitive topics. What's more, researchers learned from this research that there should be no statutory unproven, as speakers responding well to questions is very important and speak professionally during the conversation. Thus, it can be interpreted that it is possible if every time someone can flout maxim in conversation, and it will produce several reasons, and from one type of maxim can produce various reasons underlying it. The researchers suggest future research to investigate other types of flouting maxim or explore more to this discussion.

\section{REFERENCES}

Aisya, N., \& Fitrawati. (2019). An analysis of flouting of maxim performed by politician guests in Mata Najwa Talk Show in the episode of Adu Lantang Jelang Penentuan and Babak Akhir Pilpres. E-Journal of English Language \& Literature, 8(4), 42-55.

Al-Qaderi, I., \& Alduais, A. (2019). The cooperative principle in political discourse: Flouting Gricean maxims in Modern Standard Arabic political speeches. Research Result. Theoretical and Applied Linguistics, 5(3), 3-13. https://doi.org/10.18413/2313-89122019-5-3-0-1

Amer, M. A., \& Rogayah, A. R. (2017). R3: Effects of phonological and semantic cues on word learning among Jordanian preschool children with SLI. Medical Journal of Malaysia, 72(Supplement 2), 20.

Ayasreh, A. M., Al-Sabti, N., Suleiman Awwad, A., Mansoor, M., \& Razali, R. (2019). Instances of violation and flouting of the maxim by Gaddafi interview during the Arab Spring. International Journal of English and Education, 8(1), 185-193.

Aziz, Z. A., Mustafa, F., \& A'la, P. N. (2019). Flouting maxims as a sense of humor in Indonesian speech acts. Indonesian Journal of EFL and Linguistics, 4(2), 169-180. https://doi.org/10.21462/ijefl.v4i2.156

Cutting, J. (2002). Pragmatics and Discourse. London: Routledge.

Dwiwulandari, R., \& Dewanti, R. (2020). The analysis of Conversational Implicature in an Extensive Listening of BBC Learning English Podcast. In Stairs (Vol. 1, Issue 1).

Ekah, M.-H., \& Akpan, A. N. (2018). Discourse-Syntax interface: A study of Gricean Maxims in ComputerMediated Discourse. Language in India, 18(2), 187203.

Finch, G. (2000). Linguistic terms and concepts. Springer. 
Ismi Narulita Firda, Didin Nuruddin Hidayat, Alek, Nurhalimah

An Analysis of Flouting Maxim in a Talk Show Program in Indonesia

DOI: https://doi.org/10.31605/eduvelop.v4i2.887

Geis, M. L., Cole, P., \& Morgan, J. (1976). Syntax and Semantics. The Modern Language Journal, 60(5/6), 301. https://doi.org/10.2307/324613

Gumperz, J. J. (1982). Studies in Interactional Sociolinguistics 2: Language and social identity. In Discourse.

Hall, J. K., \& Walsh, M. (2002). Classroom interaction and language learning. In Annual Review of Applied Linguistics (Vol. 22, Issue 1, pp. 186-203).

Ibrahim, Z., Arifin, B., \& Setyowati, R. (2018). The flouting of maxim in the se7en movie script. Jurnal Ilmu Budaya, 2(1), 81-94.

Khosravizadeh, P., \& Sadehvandi, N. (2011). Some instances of violation and flouting of the Maxim of Quantity by the main characters (Barry \& Tim) in Dinner for Schmucks. 2011 International Conference on Language Literature and Linguistics, 26, 122-127.

Landscape, L. (2017). CONFERENCE.

Lestari, N. G. (2019). An analysis of flouting maxims in conversation Speaking of the main character in the movie of Home Alone 2 "Lost in New York" by John Hughes. Jurnal JOEPALLT (Journal of English Pedagogy, Linguistics, Literature, and Teaching), 7(1). https://doi.org/10.35194/jj.v7i1.537

Levinson, S. (1983). Pragmatics - part 1 of 2. Cambridge University Press, 1-9.

Marlisa, R., \& Hidayat, D. N. (2020). The Analysis of Flouting Maxim in Good Morning America (GMA) Talkshow. Englisia: Journal of Language, Education, and Humanities, 7(2), 137-149. https://doi. org/10.22373/ej.v7i2.6630

Nastiti, A. P. (2018). The use of Implicature to create humor as creative Principle Violation on humorous advetisement. Высшей Нервной Деятельности, 2, 227-249.

Rahmi, S. S., Refnaldi, R., \& Wahyuni, D. (2018). The violation of Conversational Maxims found in political conversation at Rosi Talkshow. E-Journal English Language and Literature, 7(1).
Rowe, B. M., \&Levine, D. P. (2018). A concise Introduction to Linguistics. In A Concise Introduction to Linguistics. https://doi.org/10.4324/9781315227283

Safitri, M. L., Seken, K., \& Putra, A. J. N. (2012). Observance and Non-Observance of Gricean Maxims in Instructional Context : an Analysis of Efl Classroom Interaction.

Schneider, K. P. (2012). Pragmatics. In Areal Features of the Anglophone World (pp. 463-486). https://doi. org/10.4324/9781315760483-11

Sembiring, E \& Ghozali, I. (2017). An analysis of maxims flouting in "The Jungle Book" movie script. Journal of English Language and Language Teaching (JELLT), 1(2), 33-39.

Taylor-Rubin, C., Croot, K., Power, E., Savage, S. A., Hodges, J. R., \& Togher, L. (2017). Communication behaviors associated with successful conversation in semantic variant primary progressive aphasia. International Psychogeriatrics, 29(10), 1619-1632. https://doi.org/10.1017/S1041610217000813

Thomas, J. (2013). Meaning in interaction: An introduction to Pragmatics. Routledge.

Virgin, J. A., \& Utami, C. P. (2017a). Dominant maxim violations in "Behind the Lawyer Profession" of Hitam Putih Talk Show. 82(Conaplin 9), 185-188. https:// doi.org/10.2991/conaplin-16.2017.40

Virgin, J. A., \& Utami, C. P. (2017b). Dominant maxim violations in "Behind the Lawyer Profession" of Hitam Putih Talk Show. 185-188. https://doi.org/10.2991/ conaplin-16.2017.40

Wahyudi, A., Yusuf, S., \& Lestari, Z. W. (2020). Maxim's flouting: An analysis of classroom interaction. Journal of English Education and Teaching (JEET), 4(1), 1-13.

Zebua, E. (2017). The violation and flouting of Cooperative Principles in the Ellen Degeneres Talk Show. Language Circle - Journal of Language and Literature, 12(1), 103-113. 